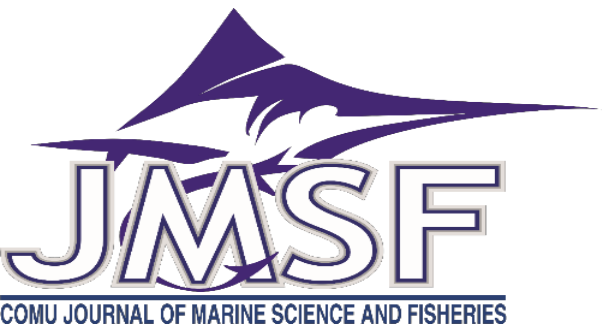

\title{
Recent Occurrence of Rare Echeneis naucrates from the Turkish Mediterranean Coast
}

\author{
Erhan Mutlu \\ Akdeniz University, Faculty of Fisheries, Dumlupınar Boulevard, 07058, Campus Antalya \\ emutlu@akdeniz.edu.tr \\ Received: 17.05.2021 Accepted:07.06.2021 \\ Orcid 0000-0002-6825-3587
}

How to cite this article: Mutlu, E., (2021). Recent occurrence of rare Echeneis naucrates from the Turkish Mediterranean coast. COMU J. Mar. Sci. Fish, 4(1): 53-62. DOI: 10.46384/jmsf.938542

\begin{abstract}
One specimen of live sharksucker was caught with a bottom trammel net in Taşucu Bay, south-eastern coast of Turkey, at $1 \mathrm{~m}$ depth on May, 2021. Meristic parameters were determined by fin ray counts and metric parameters were measured from the photos of the specimen. Excluding the recent record in Antalya Gulf, previous records of this species occurred later than May, generally in July in the Mediterranean Sea as well as in the Aegean Sea. The biometrical measurements were different in Taşucu Bay compared to those caught from the Aegean Sea and the central Mediterranean Sea (Tunisian and Sicilian waters), but relatively similar to those reported from Croatia. Major discriminative variables, albeit less significant in individuals from the central Mediterranean, were the number of anal, pectoral and dorsal fin rays. Numbers of suction disc laminae were higher in individuals from the central Mediterranean Sea and New Zealand than those from the Turkish coasts (all 21 disc laminae). The statistical analyses (Principal Component and Discriminant analyses) affirmed successful use of meristic parameters to differentiate the biometric characteristics of the species from the Aegean Sea, the central and eastern Mediterranean Sea. The length-weight relationship showed that the species had a negative allometric growth.
\end{abstract}

Keywords: Sharksucker, Biometrics, Levantine Sea, Taşucu Bay

\section{Türkiye'nin Akdeniz Kıyılarında Nadir Görülen Echeneis naucrates'in Son Kaydı}

Özet: Vantuz balığın bir bireyi Taşuçu Körfezi’nde Mayıs 2021 tarihinde $1 \mathrm{~m}$ derinlikte, fanyalı ă̆ ile yakalandı. Meristik parametreler yüzgeç ışını sayımları ile belirlendi. Metrik parametreler bireyin fotoğrafları üzerinden ölçüldü. Antalya Körfezi'ndeki son kayıt hariç, bu türün önceki kayıtları Mayıs ayından sonra, genellikle Temmuz ayında hem Akdeniz'de hem de Ege Denizi'nde gerçekleşmiştir. Taşuçu Körfezi'nde yakalanan bireyin biyometrik ölçümleri Ege Denizi ve orta Akdeniz'de (Tunus ve Sicilya suları) yakalananlarla karşılaştırıldığında farklı iken, Hırvatistan'dan bildirilenlere nispeten benzer bulunmuştur. Orta Akdeniz'deki bireylerde daha az önemli olsa da ana ayırıcı parametrelerin anal, pektoral ve dorsal yüzgeç 1şınlarının sayısı olduğu tespit edilmiştir. Orta Akdeniz ve Yeni Zelanda'daki bireylerde vantuz disk laminalarının sayısı Türkiye kıyılarındaki bireylere göre daha yüksek (21 disk laminasının tamamı) bulunmuştur. İstatistiksel analizler (Principal Component ve Diskriminant analizleri), Ege Denizi, Orta ve Doğu Akdeniz'deki bireylerin biyometrik özelliklerini ayırt etmede meristik parametrelerin etkili olduğunu ortaya koymuştur. Boy-ağırlık ilişkisi, türün negatif allometrik büyümeye sahip olduğunu göstermiştir.

Anahtar Kelimeler: Vantuz Balığı, Biyometrileri, Levant Denizi, Taşuçu Körfezi 


\section{Introduction}

Suckerfishes (Remora) belong to the family of Echeneidae of bony fishes and are represented with only eight species in the world (Gray et al., 2009; WoRMS). They have a sucking disc on their heads which stick to a variety of large marine organisms such as marine mammals, turtles, sharks and teleosts (Battaglia et al., 2015). Five species of remoras were found in the Mediterranean Sea (Gray et al., 2009). Of these, four species, Echeneis naucrates Linnaeus, 1758, Remora australis (Bennett, 1840), Remora remora (Linnaeus, 1758) and Remora osteochir (Cuvier, 1829) reported from the Turkish waters (Bilecenoglu et al., 2014).

The sharksucker fish, Echeneis naucrates Linnaeus, 1758 is common in tropical and temperate waters of the world (Cervignón et al., 1992) and appears as a Lessepsian fish in the eastern Mediterranean Sea (Insacco et al., 2015-2016). The sharksuckers are often free-swimmers in shallow waters (Smith, 1997).

The occurrence of Echeneis naucrates was reported from different parts of the Mediterranean Sea, particularly in the eastern, (Lachner, 1986; Papaconstantinou, 1988; Golani et al., 2006), southern and the central coasts of the Mediterranean Seas (Tortonese, 1973; Al-Hassan and El-Silini, 1999; Bradai et al., 2004). The occurrence of the live sharksucker is seasonal, and limited to summer months (July), but recent reports indicate earlier occurences (May) (de Meo et al., 2018; present study), due, possibly to, global and regional climate change.

There are a total of 10 earlier studies that report the occurrence of Echeneis naucrates from the Turkish waters (e.g. Gücü and Bingel, 1994; Başusta and Erdem, 2000; Beğburs and Kebapcioğlu, 2007; Akyol and Balık 2007; Gökçe et al., 2016) of the Mediterranean Sea and of the Aegean Sea (Akyol, 2013; Akyol and Capape, 2015). The aim of the present study is, in addition to report the occurrence of Echeneis naucrates from a new location in Turkish waters, is to determine their biometrics, and to compare them with biometrics of the previously reported specimens from the different regions of the Mediterranean Sea.

\section{Material and Methods}

A specimen of Echeneis naucrates, caught by a local fisherman, was brought to the Lab7 laboratory of Fisheries Faculty, Akdeniz University on May 12, 2021. Following determination of biometric parameters, the specimen was transferred to the museum Fisheries Faculty, Akdeniz University.

The specimen was caught with a trammel net on a sandy bottom at a depth of $1 \mathrm{~m}$ in Taşucu Bay, Turkey (36 $16^{\prime} 15.25^{\prime \prime} \mathrm{N}$ and $\left.33^{\circ} 54^{\prime} 99.74^{\prime \prime} \mathrm{E}\right)$ on
May 12, 2021 (Mutlu, E., pers. comm.; Figure 1). The capture of suckerfish was evaluated as an unintentional entanglement of the host fish, which was assumed to extricate itself from the trammel net after struggling as indicated by the presence of largesize holes and tear marks on the net. (Mutlu, E., pers. comm.).

The specimen was identified according to descriptions by Strasburg (1964), Paulin and Habib (1982), O’Toole (2002) and Golani et al. (2006).

Biometric measurements (metric and meristic parameters) were performed on site (Table 1). Metric parameters were measured and digitized from the photo of the specimen using Surfer 12 (Golden software inc.). The metric and meristic measurements in centimeter and number were performed from the specimen as follows in Table 1a and $\mathrm{b}$, respectively. Ratios of all metric variables to the total length and standard length were then calculated, and were offered for the comparison of other specimens previously published (see Table 3 for the details).

During counting of the dorsal and anal fin rays, the dorsal fin and anal fin were considered into two parts each to formulize the rays. Heights of the first parts of the fins were more (D1 and A1) than the second part (D2 and A2) (Figure 2a, b). Number of laminae and cups on the head sucker disc was identical for the species (Figure 2c). Furthermore, maxilla dentary characteristics were examined on the jaws of the specimen (Figure 2d, e).

The specimen was described following a paper published by Paulin and Habib (1982). In addition, the literature knowledge was gathered in a matrix of the biometrics of the species recorded from different regions of the Mediterranean Sea for the discussion (Paulin and Habib, 1982; Akyol and Balık 2007; Skaramuca et al., 2009; Akyol, 2013; Akyol and Capape, 2015; Insacco et al., 2015-2016; RafrafiNouira et al., 2015). The matrix of the normalized data was subjected to the Principal Component Analyses (PCA) for the possible regional difference in the biometrics using the PRIMER 6. Consequently, the Discriminant Analysis was used to test statistically the significance of the differences hypothesized accordingly between the central and eastern Mediterranean Seas, and among the regions of the Aegean Sea, the central and eastern Mediterranean Seas using STATISTICA.

The length-weight relationship (LWR) was established with the data compiled from the literatures aforementioned in an addition to the findings in Antalya Gulf (Mutlu et al., 2016) and the present study using the MATLAB since the LWR was lacked in the literatures for the Mediterranean Sea (https: // www.fishbase.se/ summary/Echeneisnaucrates.html) owing to difficulties to acquire the 


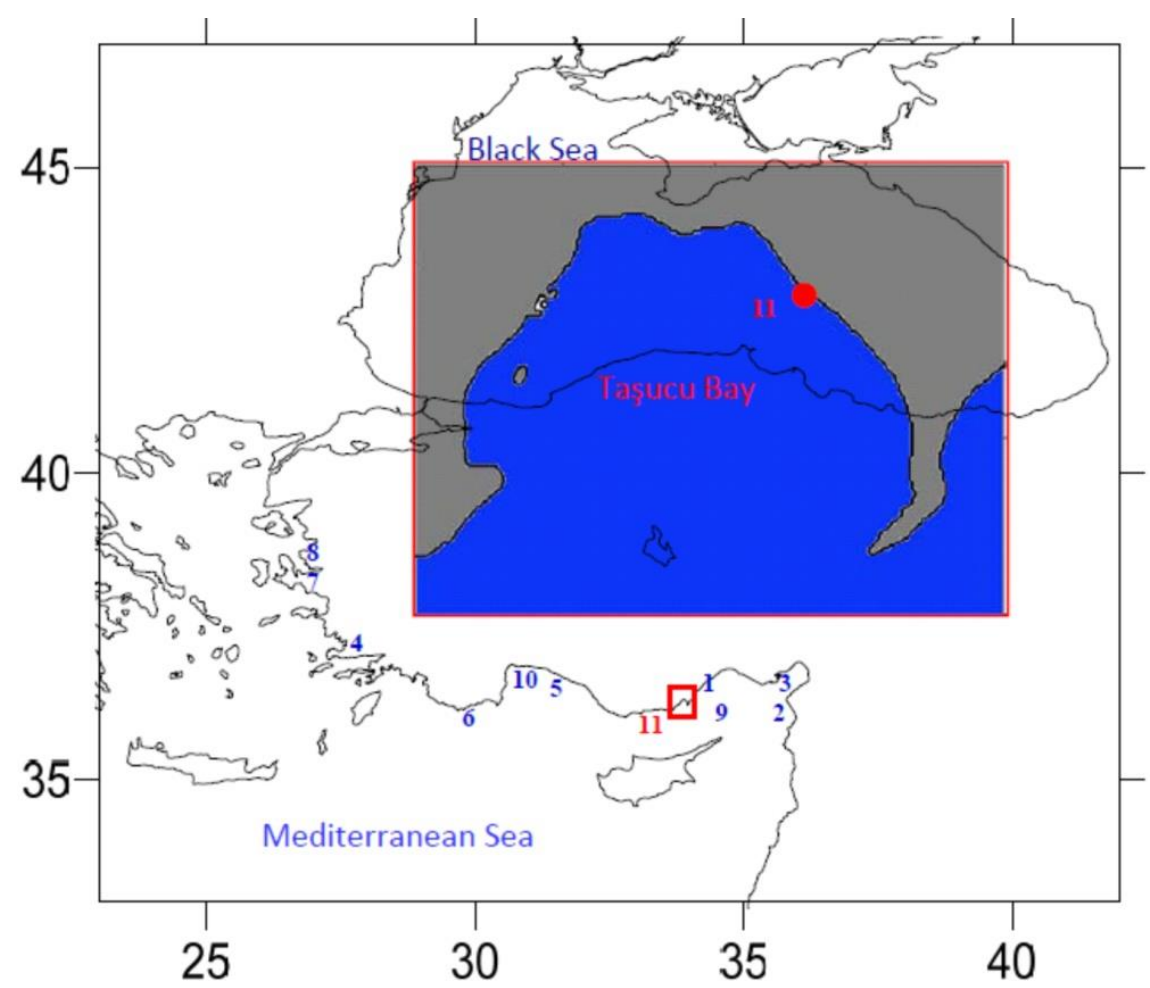

Figure 1. Updated chronological locations of occurrences of live sharksucker fish along the Turkish coasts (1, Gücü and Bingel, 1994; 2, Başusta and Erdem, 2000; 3, Başusta et al., 2002; 4, Öğretmen et al., 2005; 5, Beğburs and Kebapcioğlu, 2007; 6, Akyol and Balık 2007; 7, Akyol, 2013; 8, Akyol and Capape, 2015; 9, Gökçe et al., 2016; 10; de Meo et al., 2018 and 11, present study area in red dot).

specimens. The t-student statistic was applied to the estimated $b$ value to test significance of the difference from the isometric $b$ value.

\section{Results}

The specimen had a total length of $44 \mathrm{~cm}$ and weight of $320 \mathrm{~g}$ (Figure 1 and Figure 2). The standard length was $38.5 \mathrm{~cm}$ and head sucker disc was $9.3 \mathrm{~cm}$ long and $4.0 \mathrm{~cm}$ wide (Table 1).

Specimen was elongated in shape with relatively broader head. The sucker disc was located between tip of upper jaw and distal tip of the pectoral fin base (Figure 2a, c). The disc had 21 laminea with cups slightly curved backward. There was one anal and dorsal fin; each have whitish front part of the fins having longer anterior rays (D1 and A1) compared to their posterior parts (D2 and A2) of the fins (Figure $2 \mathrm{a}, \mathrm{b})$. Dorsal body was blackish gray and ventral body was whitish-gray in color. Pectoral fin was pointed and caudal fin (tail) emarginated (Figure 2a, b). Mouth was superior positioned (Figure 2a). Dentary of premaxilla was characterized with villiform teeth (Figure 2e). Palatine patch was composed of mostly canine and few incisor teeth (Figure 2d).

\section{Material examined (one specimen).}

Eastern Mediterranean Sea, district of "Kum Mahallesi”, Taşucu Bay, Turkey, 12 May 2021, 36 $18^{\prime} 15^{\prime \prime} \mathrm{N}$ and $33^{\circ} 54^{\prime} 99^{\prime \prime}$ E., $38.5 \mathrm{~cm} \mathrm{SL}$.

\section{Description.}

Disc laminae 21; first dorsal rays 7 and second dorsal rays 28, first anal rays 10 and second anal rays 19 , pectoral rays 18 , pelvic rays III, 4 and caudal rays 15. Body elongate, slender, caudal peduncle tapered; head depressed (Figure 2a-b). Disc extending to distal end of pectoral fins (Figure 2c). Mouth posterior, and lower jaw extending beyond upper jaw (Figure 2a-b). Numerous small, villiform teeth in both jaws more in lower than upper jaws (Fig. 2d-e), some teeth on tongue (Figure 2d). Dorsal originating at middle of standard length, dorsal fin slightly beyond anal fin, higher at anterior end than posteriorly (Figure 2a-b). Caudal fin emarginated (Figure 2a). 

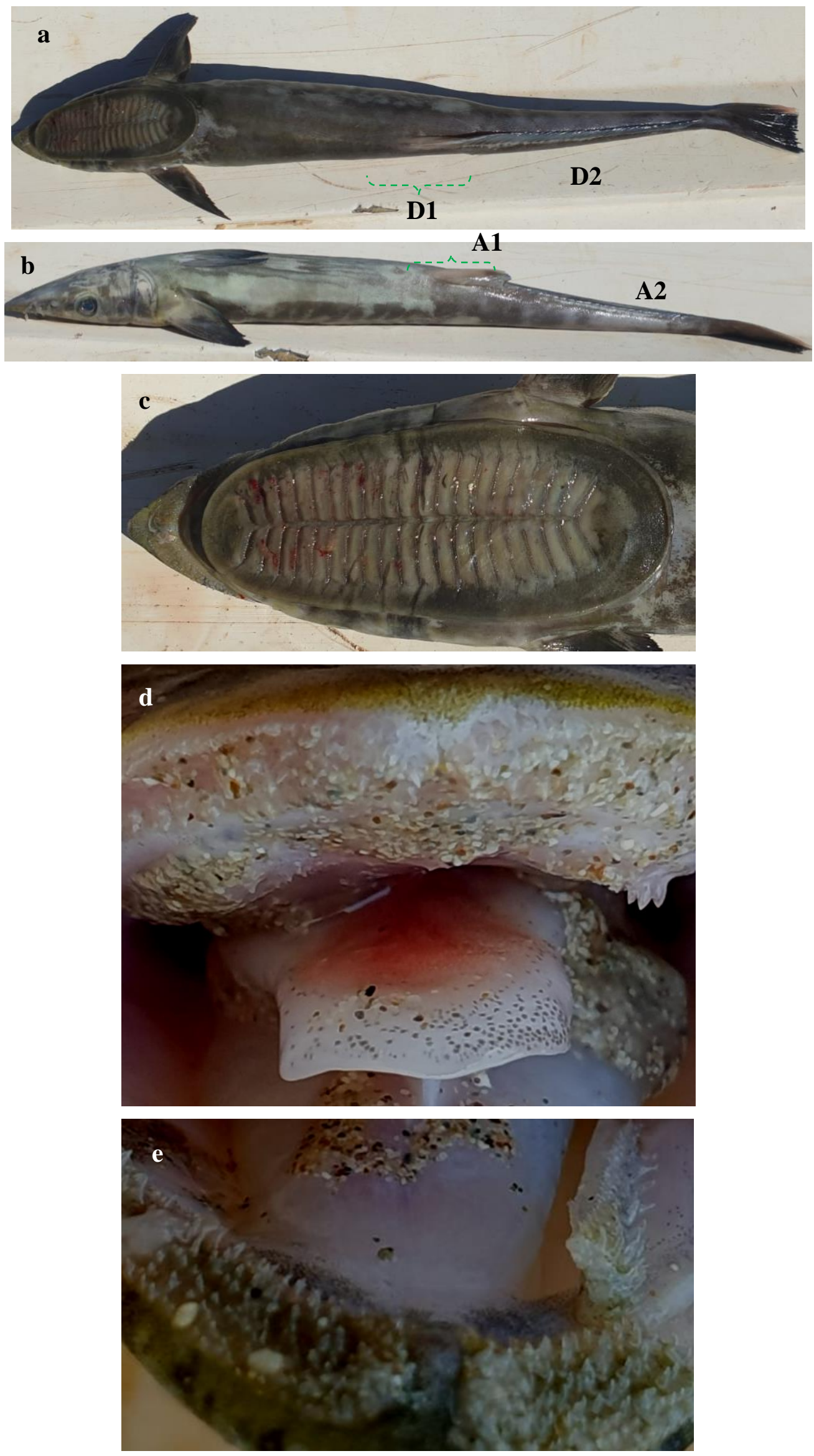

Figure 2. Echeneis naucrates; top view (a), lateral view (b), disc laminae (c), the upper (d) and lower jaws (e). (Photos: Orhan Mutlu). 
Dimensions as \% SL; total length 114.3, orbit diameter 3.4, disc length 2.2; 2.3 times greater than width 10.4 , preanal length 61.8 longer than predorsal length 57.1, and length of dorsal 39.2 shorter than anal fin 44.2 (Table 2). Dimensions as \% HL; eye diameter 15.3 and pre-orbital length 49.4
Color uniform dark gray dorsally, pale patches laterally, pale whitish-gray extending to distal of anal fin ventrally and patchy dark gray on pale background at rest to peduncle ventrally (Figure $2 \mathrm{a}, \mathrm{b})$.

Table 1. Metric and meristic characteristics of Echeneis naucrates and their biometrics percent ratios to total length

\begin{tabular}{|l|c|c|}
\hline Traits & Measures (cm) & \%Ratio to TL \\
\hline Total length, TL & 44 & 100 \\
\hline Standard length, SL & 38.5 & 87.5 \\
\hline Disc length, DL & 9.3 & 21.1 \\
\hline Disc width, DW & 4 & 9.1 \\
\hline DL/DW & 2.3 & \\
\hline Post-disc length, PDL & 10.1 & 23.0 \\
\hline Head length, HL & 7.1 & 16.1 \\
\hline Post-operculum length, POL & 8.5 & 19.3 \\
\hline Pre-dorsal length, PDoL & 22 & 50.0 \\
\hline Pre-anal length, PAL & 23.8 & 54.1 \\
\hline Eye diameter, ED & 1.3 & 3.0 \\
\hline Pre-orbital length, POrL & 4.2 & 9.5 \\
\hline Dorsal fin length, DL & 15.1 & 34.3 \\
\hline Anal fin length, AL & 17 & 38.6 \\
\hline Pre-pectoral length, PPL & 7.5 & 17.0 \\
\hline Pectoral fin length, PL & 5.0 & 11.3 \\
\hline Pelvic fin length, PeL & 5.2 & - \\
\hline Caudal fin length, CL & 5.5 & - \\
\hline Number of disc laminae, NL & 21 & - \\
\hline Number of anal fin ray, NA & $10+19$ & - \\
\hline Number of dorsal fin ray, ND & $7+28$ & - \\
\hline Number of pectoral fin ray,NP & 18 & - \\
\hline Number of pelvic fin ray, NPe & III+4 & - \\
\hline Number of caudal fin ray, NC & 15 & - \\
\hline Weight (g), W & 320 & - \\
\hline
\end{tabular}

\section{Distribution in Turkish waters.}

A circumtropical fish, Lessepsian to the eastern Mediterranean (Insacco et al., 2015-2016); chronologically Mersin Bay (Gücü and Bingel, 1994), Iskenderun Bay (Başusta and Erdem, 2000), Iskenderun Bay (Başusta et al., 2002), Gökova Bay, SE Aegean Sea (Öğretmen et al., 2005), Gulf of Antalya (Beğburs and Kebapcioğlu, 2007), Beymelek Lagoon off Antalya (Akyol and Balık, 2007), Izmir Bay, NE Aegean Sea (Akyol, 2013; Akyol and Capape, 2015), Mersin Bay (Gökçe et al., 2016), Gulf of Antalya (de Meo et al., 2018) and Taşucu Bay (present study) (Figure 1).

\section{Discussion}

Earlier reports of sharksuckers indicate that this species commonly occurred in mid summer (July) or later at very shallow waters (Akyol and Balık, 2007; Skaramuca et al., 2009; Akyol, 2013; Akyol and Capape, 2015; Rafrafi-Nouira et al., 2015; Insacco et al., 2015-2016; Marletta and Lombardo, 2020). Recently the species appeared earlier; de Meo et al. (2018) reported in May in Antalya Gulf as occurred in the present study. Due to the difference in temperature by time, appearance of the species could occur in different time in the Mediterranean Seas. 
Furthermore, the temperature could change timing of sharksucker occurrence depending on response of host of the sharksuckers to the temperatures (Friedman et al., 2013) even though the sharksuckers were occasionally free-swimmer (Collette, 2016).

Metric and meristic measurements of the specimen were in accordance with those from other locations in Turkish coasts (Table 2 and Figure 3). However, specimens were rather different in terms of the measurements along coasts of Sicily and Tunisia (central Mediterranean Sea) than the eastern
Mediterranean Sea (Table 2 and Figure 3). The species occurred very rarely in the northwestern Mediterranean Sea, and were mostly common in the eastern (Lachner, 1986; Papaconstantinou, 1988; Golani et al., 2006) and central Mediterranean Seas (Tortonese, 1973; Al-Hassan and El-Silini, 1999; Bradai et al., 2004). Specimens in New Zealand had different biometrics compared to those reported from the Mediterranean Sea and had longer HL, PDoL and DL (Table 2 and Figure 3).

Table 2. Percent metric parameters to total length (red number to head length) and absolute meristic parameters of the live sharksuckers in the Mediterranean Seas (PS; present study area, Be; Belek lagoon, Iz; İzmir Bay in Aegean Sea, Cr; Croatian coast in Adriatic Sea, Si; Sicily in Tyrrhenian and Ionian Seas, Tu; Tunisian coast) and Nz; New Zealand (ratios to standard length) (see Tables 1 for the abbreviations of the traits)

\begin{tabular}{|c|c|c|c|c|c|c|c|c|c|c|}
\hline Traits & PS & Be & $\mathbf{I z}$ & $\mathbf{I z}$ & $\mathrm{Cr}$ & $\mathrm{Si}$ & $\mathrm{Si}$ & $\mathbf{T u}$ & $\mathbf{N z}$ & $\mathrm{Nz}$ \\
\hline SL & 87.5 & & 89.3 & & 87.9 & 84.4 & 84.2 & 90.4 & & \\
\hline DL & 21.1 & & & 20.8 & & 22.1 & 21.8 & 20.8 & 22.5 & 22.9 \\
\hline DW & 9.1 & & & & & 9.4 & 8.3 & 7.9 & 8.2 & 6.9 \\
\hline DL/DW & 5.2 & & & & & 2.4 & 2.6 & 2.4 & 2.7 & 3.3 \\
\hline PDL & 23.0 & & & & & & & & & \\
\hline $\mathrm{HL}$ & 16.1 & 16.8 & 16.3 & 15.3 & 16.3 & & & & 18.0 & 18.1 \\
\hline POL & 19.3 & & & & & 16.8 & 15.1 & 16.5 & & \\
\hline PDoL & 50.0 & & 44.1 & 46.6 & 34 & 47.5 & 45.6 & 46.2 & 51.8 & 48.9 \\
\hline PAL & 54.1 & 46.1 & 45 & 49.1 & 45.9 & 47.3 & 45.0 & 44.2 & & \\
\hline ED & 15.3 & 12.5 & 13.3 & 13.6 & 16.4 & 12.5 & 12.8 & 11.6 & 12.8 & 12.7 \\
\hline POrL & 49.4 & 37.5 & 38.7 & 42 & 44.8 & 42.0 & 43.6 & 51.2 & & \\
\hline DL & 34.3 & & & & & 37.0 & 36.3 & 34.6 & 44.1 & 44.3 \\
\hline $\mathrm{AL}$ & 38.6 & & & & & 35.9 & 37.1 & & & \\
\hline PPL & 17.0 & 17.1 & & 16 & 20.6 & & & 17.3 & & \\
\hline PL & 11.4 & & & & 17.7 & 12.4 & 11.8 & 3.7 & & \\
\hline PL & 11.8 & & & & & 10.3 & 10.0 & 3.3 & & \\
\hline CL & 12.5 & & & & 0.0 & 15.5 & 15.3 & 4.0 & & \\
\hline NL & 21 & 21 & 21 & 21 & 23 & 23 & 23 & 22 & 23 & 25 \\
\hline NA & $10+19$ & 37 & 36 & & 35 & VII,9 & VII,9 & 26 & & \\
\hline ND & $7+28$ & 37 & 34 & & 37 & VIII,10 & VIII,10 & 28 & 36 & 39 \\
\hline NP & 18 & 21 & 18 & & 23 & 15 & 15 & 15 & & \\
\hline $\mathrm{NPe}$ & $\mathrm{III}, 4$ & $\mathrm{~V}, 5$ & $\mathrm{I}, 5$ & & IV,5 & $\mathrm{I}, 3, \mathrm{I}$ & $\mathrm{I}, 3, \mathrm{I}$ & 5 & & \\
\hline $\mathrm{NC}$ & 15 & & & & & & & & & \\
\hline $\mathrm{W}$ & 320 & & & & 165 & 565 & 570 & 350 & & \\
\hline Citation & 1 & 2 & 3 & 4 & 5 & 6 & 6 & 7 & 8 & 8 \\
\hline
\end{tabular}

(Citations: 1; present study, 2; Akyol and Balık 2007, 3; Akyol, 2013; 4; Akyol and Capape, 2015, 5; Skaramuca et al., 2009, 6; Insacco et al., 2015-2016, 7; Rafrafi-Nouira et al., 2015, 8; Paulin \& Habib, 1982). 
The NL was higher in number in individuals from the central Mediterranean Sea and New Zealand than those from the Turkish coasts. Also ED was wider, hence PDoL was shorter (Table 2 and Figure 3).

However, specimens from Sicily had less fin rays than those from the Turkish waters. Hard rays were present only in the pelvic fins of specimens from Turkish and Croatian waters. Hard rays were available also in dorsal and anal fins only in Sicilian specimens (Table 2). The ED, PDoL, PAL, NA and HL discriminated the measurements of the present study from those reported from other locations in Turkey (Table 2 and Figure 3).

The PCA showed that biometrics of the species in the Eastern Mediterranean Sea were discriminated from the central Mediterranean Sea on axis PCA1 (Figure 3). This difference was explained with a percent variance of 47.2. The variables of the biometrics were NA, NP and ND in negative correlations and they were major factors for the discriminations, followed variables of PDoL (positive Eigen value) and NPe (negative) (Figure 3). On the PCA2, Aegean Sea (Izmir Bay) and Beymelek lagoon close relatively to the Aegean Sea were separated from the Croatian and the present study (Figure 3). However, the central Mediterranean biometrics were not affected throughout the PCA2 which was explained with a cumulative variance of 70.0 with major variables of ED, POrL and HL, followed by NL (Figure 3).

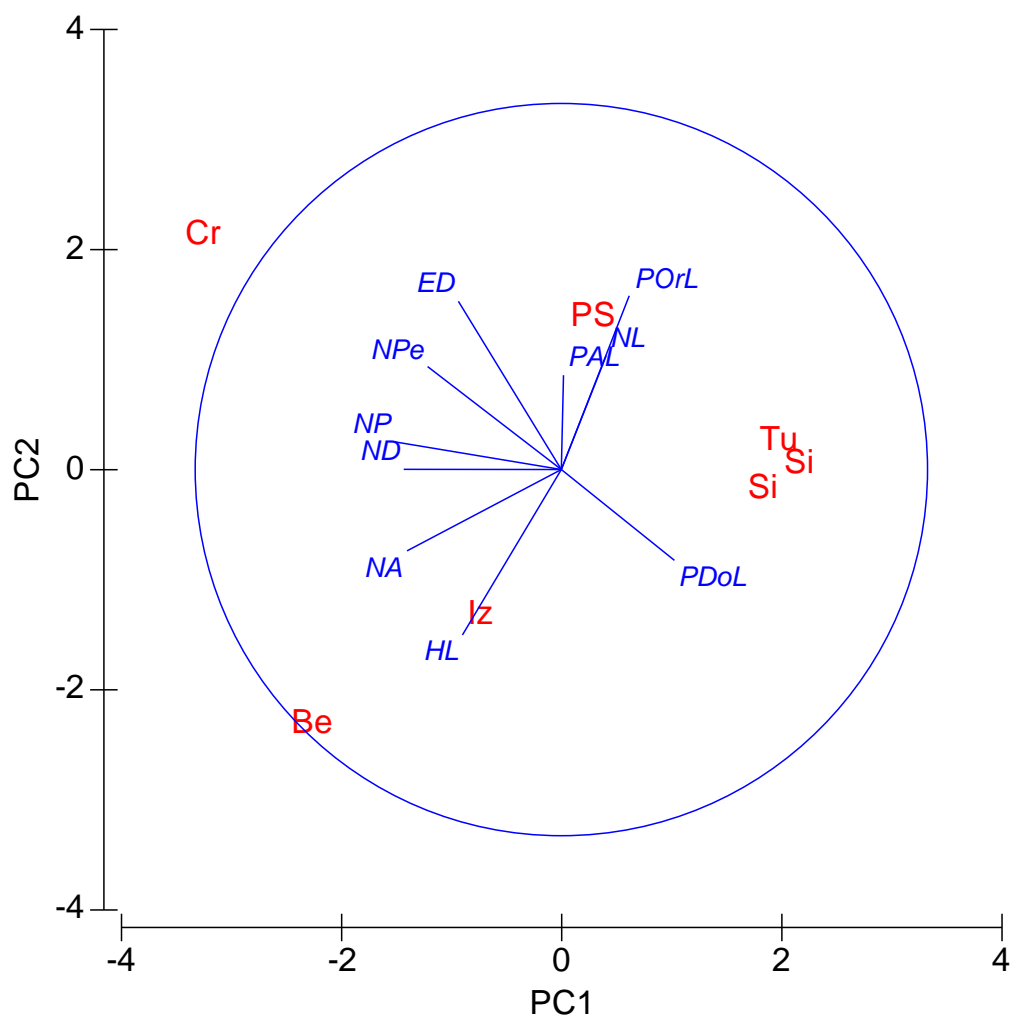

Figure 3. PCA ordination of absolute meristic and percent metric measurements of the live sharksucker in the Mediterranean Sea (the data compiled from the literatures in Table 3) (see Tables 1 and 2 for the abbreviations of the parameters and locations).

The Discriminant Analysis showed good accordance with the results of PCA (Table 3 and Figure 3). The distances for the meristic parameters were significantly different between groups of among the Aegean Sea (AS), central (CM) and eastern Mediterranean Sea (EM) at $p<0.05$. The partial correlation of the discriminant variables had low values. The NA, ND and NP were effective significantly between $\mathrm{CM}$ and EM whereas ED, NA and ND were among AS, ES and CM (Table 3). However, the NL did not differentiate the specimens among the regions of the Mediterranean Sea since the NL was effective on the PCA2.
The total length and weight relationship (LWR) of sharksuckers was lack for the Mediterranean Sea (https://www.fishbase.org/popdyn/LWRelationshipLi st.php ? ID $=2467 \&$ GenusName $=$ Echeneis $\&$ SpeciesName $=$ naucrates $\&$ fc $=313$ ). The relationship was well correlated for the species even though the measurements were compiled from different locations and date in the Mediterranean. The constants of the regression were significantly fitted for the LWR curve ( $\mathrm{p}$ for $a=0.0231, \mathrm{p}$ for $b=0.0001$, and $n=7)$. 
Table 3. Results of the discriminant analysis to test differences in common biometrics of sharksuckers in the Mediterranean specimens among the Aegean Sea (AS), central (CM) and eastern Mediterranean Sea (EM) (see Tables 1 for the abbreviations of the traits). Bold $p$ values denote significantly different at $\mathrm{p}$ $<0.05$

\begin{tabular}{|c|c|c|}
\hline Variables & Partial Wilks' Lamda & p \\
\hline \multicolumn{3}{|c|}{ Between the CM and EM } \\
\hline $\mathrm{HL}$ & 0.845 & 0.383 \\
\hline PDOL & 0.906 & 0.505 \\
\hline PAL & 0.869 & 0.426 \\
\hline ED & 0.585 & 0.118 \\
\hline PORL & 0.901 & 0.492 \\
\hline NL & 0.611 & 0.134 \\
\hline NA & 0.237 & 0.010 \\
\hline ND & 0.062 & 0.001 \\
\hline NP & 0.276 & 0.015 \\
\hline NPE & 0.740 & 0.242 \\
\hline \multicolumn{3}{|c|}{ Among the AS, CM and EM } \\
\hline HL & 0.485 & 0.235 \\
\hline PDOL & 0.846 & 0.717 \\
\hline PAL & 0.578 & 0.335 \\
\hline ED & 0.095 & 0.009 \\
\hline PORL & 0.382 & 0.145 \\
\hline NA & 0.115 & 0.013 \\
\hline ND & 0.060 & 0.003 \\
\hline NP & 0.262 & 0.068 \\
\hline NPE & 0.588 & 0.346 \\
\hline
\end{tabular}
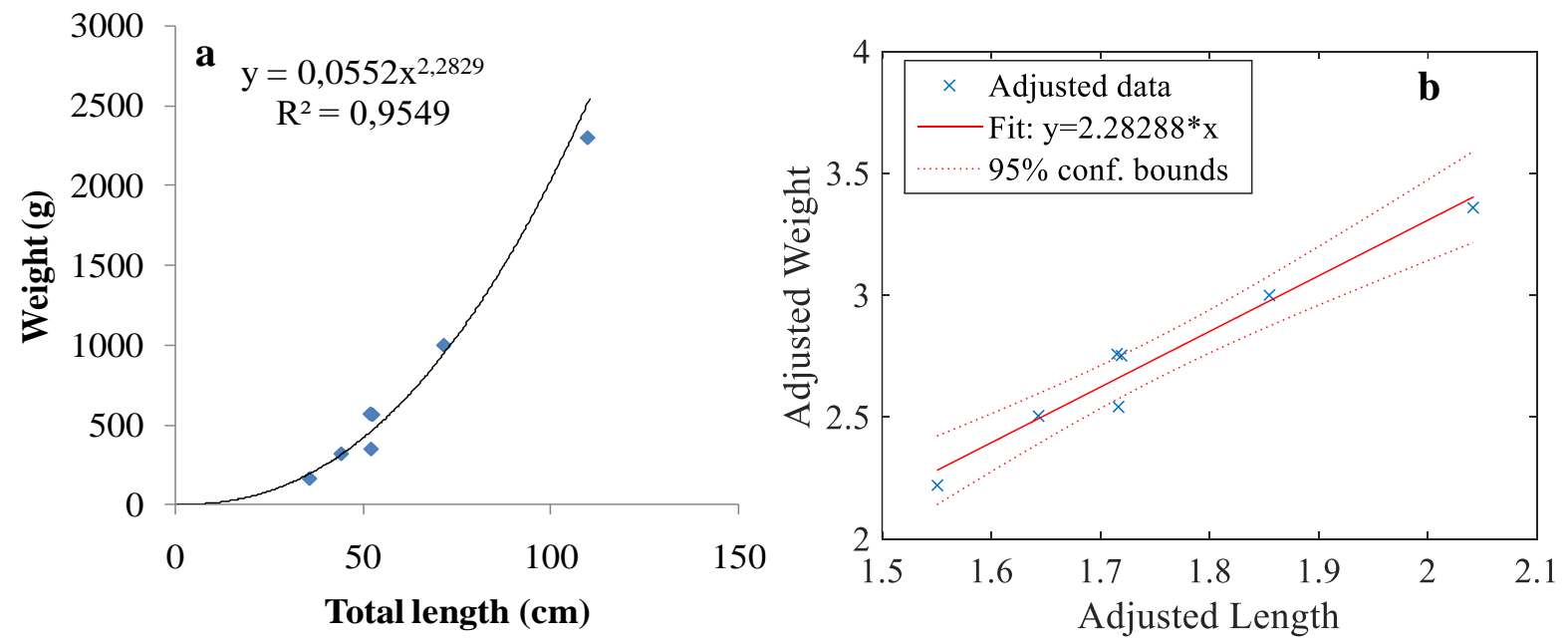

Figure 4. Total Length-weight relationship (a) and $\log _{10}(\mathrm{LWR})$ (b) of the sharksucker (the data gathered from the measurements reported in Skaramuca et al., 2009; Insacco et al., 2015-2016; 6; Rafrafi-Nouira et al., 2015; Mutlu et al., 2016; Froese and Pauly, 2021).

According to Fishbase, there are three LWR equations for the southern Florida offshore and Pacific Ocean (New Caledonia) and all specimens were sexually mixed or unsexed. Overall, reported regression coefficients were rather different than that estimated in the present study. However, the LWR estimated for the southern Florida was not reliable markedly by Fishbase. The $b$ values were greater than 3 in the Pacific Ocean whereas the $b$ value estimated in the present study was less than 3 , and significantly different from the isometric growth (t-test; $\mathrm{t}=$ $3.2325, \mathrm{n}=7$ ) at $\mathrm{p}<0.05$. The growth type was negative allometry (Figure 4). Furthermore, the intercept values estimated in Fishbase were rather 
than the intercept, $a$ value found in the present study. This could be due to the regional differences in the environments.

\section{Acknowledgments}

I thanked Muharrem T. Mutlu and Orhan Mutlu for their helps during photography of the specimen.

\section{Conflict of Interests}

The author declares that there are no conflicts of interests.

\section{Author contribution}

Erhan Mutlu designed, performed and wrote the manuscript.

\section{References}

Akyol, O. \& Capape, C. (2015). On the occurrence of live sharksucker, Echeneis naucrates Linnaeus, 1758 (Perciformes: Echeneidae), in Turkish waters (Eastern Mediterranean. Journal of Applied Ichthyology, 31, 744-746.

Akyol, O. (2013): Record of the live sharksucker, Echeneis naucrates Linnaeus, 1758 (Osteichthyes: Echeneidae), from the northern Aegean Sea (Izmir Bay, Turkey). J Journal of Applied Ichthyology, . 29, 263-264.

Akyol, O., \& Balık, I. (2007). Occurrence of the live sharksucker, Echeneis naucrates (Echeneidae), in the Beymelek Lagoon, Turkey (eastern Mediterranean). Cybium, 31, 487-488.

Al-Hassan L.A.J., \& El-Silini O.A. (1999). Check-list of bony fishes collected from Mediterranean coast of Bengazi, Lybia. Revista de Biología Marina y Oceanografia, 34, 291-301.

Başusta, N., \& Erdem, U. (2000). A study on the pelagic and demersal fishes of Iskenderun Bay, eastern Mediterranean. Turkish Journal of Zoology, 24 (Suppl.), 1-19.

Başusta, N.; Kumlu, M., Gökçe, M.A., \& Göçer, M. (2002). Seasonal change and productivity index of species by trawl in Yumurtalık Bay. Ege Journal of Fisheries and Aquatic Sciences, 19, 29-34.

Battaglia, P., Potoschi, A., Valastro, M., Andaloro, F., \& Romeo T. (2016). Age, growth, biological and ecological aspects of Remora osteochir (Echeneidae) in the Mediterranean Sea. Journal of the Marine Biological Association of the United Kingdom, 96, 639-645.

Beğburs, R.C., \& Kebapcioğlu, T. (2007). An investigation on catch composition of bottom trammel nets used in Antalya, Boğazkent. Ege Journal of Fisheries and Aquatic Sciences, 24, 283-286.
Bilecenoglu, M., Kaya, M., Cihangir, B., \& Çiçek, E. (2014). An updated checklist of the marine fishes of Turkey. Turkish Journal of Zoology, 38(6), 901-929.

Bradai, M.N., Quignard, J.P., Bouain, A., Jarboui, O., Ouannes-Ghorbel, A., Ben Abdallah, L., Zaouali, J., \& Ben Salem, S. (2004). Ichtyofaune autochtone et exotique des cotes tunisiennes: Recensements et biogéographie. Cybium, 28, 315328.

Collette, B.B. (2016). Echeneidae. In: K.E. Carpenter, N. De Angelis (Eds.). The living marine resources of the Eastern Central Atlantic. Volume 4. Bony fishes part 2 (Perciformes to Tetraodontiformes) and Sea turtles. FAO Species Identification Guide for Fishery Purposes, Rome, FAO.

de Meo, I., Miglietta, C., Mutlu, E., Deval, M.C., Balaban, C., \& Olguner, T.M. (2018). Ecological distribution of demersal fish species in space and time on the shelf of Antalya Gulf, Turkey. Marine Biodiversity, 48, 2105-2118. https://doi.org/10.1007/s12526-017-0739-7

Friedman, M., Johanson, Z., Harrington, R.C., Near, T.J., \& Graham M.R. (2013). An early fossil remora (Echeneoidea) reveals the evolutionary assembly of the adhesion disc. Proceedings of the Royal Soceity B: Biological Science, 280: 1766.

Froese, R.; \& Pauly, D. (2021). FishBase. World Wide Web electronic publication. Available at: www.fishbase.org. (visited on 16 July 2021).

Gökçe G., Saygu, I., \& Eryaşar, A.R. (2016). Catch composition of trawl fisheries in Mersin Bay with emphasis on catch biodiversity. Turkish Journal of Zoology, 40, 522-533. doi:10.3906/zoo-150535

Golani, D., Öztürk,B. \& Başusta, N. (2006). Fishes of the Eastern Mediterranean. Istanbul, Turkey: Turkish Marine Research Foundation. Publication Number: 24, 259 p.

Gray, K.N., Mc Dowell, J.R., Collette, B.B., \& Graves J.E. (2009). A molecular phylogeny of the remoras and their relatives. Bulletin of Marine Science, 84(2), 183-197.

Gücü, A.C.; \& Bingel, F. (1994). Trawlable species assemblages on the continental shelf of the northeastern Levant Sea (Mediterranean) with an emphasis on Lessepsian migration. Acta Adriatica, 35, 83-100.

Insacco, G., Amato, A. \& Zava, B. (2015-2016). Records of live sharksucker Echeneis naucrates Linnaeus, 1758 in Tyrrhenian and Ionian Seas (Osteichthyes, Echeneidae). Natura Rerum, 4, 4951. 
Lachner, E.A. (1986). Echeneididae. In: Fishes of the north-eastern Atlantic and the Mediterranean, Vol. III. P. In: J. P. Whitehead, M. L. Bauchot, J. C. Hureau, J. Nielsen \& E. Tortonese (Eds.) UNESCO, Paris, pp. 1329-1334.

Marletta, G., \& Lombardo, A. (2020). A new record of the live sharksucker, Echeneis naucrates Linnaeus, 1758 (Perciformes, Echeneidae), in the Mediterranean Sea. Thalassia Salentina, 42, , 129134.

Mutlu E., Deval, M.C., De Meo, I., Miglietta C., Balaban C., \& Olguner, M.T. (2016). Antalya Körfezi'nin demersal ve yar1-demersal balıklarının çevresel parametrelere bağlı olarak dağılımı. Proje Final raporu, 2014.01.0111.001, Akdeniz Üniversitesi Bilimsel Araştırma Projeleri Koordinasyon Birimi, 135 pp.

O'Toole B. (2002). Phylogeny of the species of the superfamily Echeneoidea (Perciformes: Carangoidei: Echeneidae, Rachycentridae, and Coryphaenidae), with an interpretation of echeneid hitchhiking behaviour. Canadian Journal of Zoology, 80, 596-623. DOI:10.1139/Z02-031

Öğretmen, F.; Yılmaz, F., \& Koç T.H. (2005). An investigation on fishes of Gökova Bay (Southern Aegean Sea). BA $\ddot{U}$ Fen Bilimleri Enstitüsü Dergisi, 7, 19-36.

Papaconstantinou, C. (1988). Check-list of marine fishes of Greece. Fauna Graeciae IV, National Centre for Marine Research, Athens, 257 pp.
Paulin, C.D. \& Habib G. (1982) Remoras (Pisces: Echeneidae) from New Zealand. New Zealand Journal of Zoology, 9(1), 33-36. DOI: 10.1080/03014223.1982.10423834

Rafrafi-Nouira S., Reynaud, C., Boumaïza, M., El Kamel_Moutalibi, O., \& Capapé, C. (2015). Unusual captures of teleost species from the northern coast of Tunisia (central Mediterranean). Journal of Ichthyology, 55(3), 337-345.

Skaramuca D., Skaramuca, B., \& Dulcic, J. (2009). Record of a live sharksucker, Echeneis naucrates (Osteichthyes: Echeneidae) from the southeastern Adriatic (Croatian coast). Marine Biodiversity Records, 2, e80. doi:10.1017/S1755267209000694; 2009.

Smith, C.L. (1997). National Audubon Society Field Guide to Tropical Marine Fishes of the Caribbean, the Gulf of Mexico, Florida, the Bahamas, and Bermuda. Knopf Publishing Group, New York: 720 pp.

Strasburg, D.W. (1964). Further Notes on the Identification and Biology of Echeneid Fishes. Pacific Science, XVIII, 51-57.

Tortonese, E. (1973). Les poissons de la famille Echeneididae (Remoras) de la Mer Ligure et de la Mer Tyrrhénienne. Revue des travaux de l'Institut des pêches maritimes, 37(2), 197-202. 